\title{
EL COVID-19 Y SU IMPACTO EN EL MEDIO AMBIENTE
}

Antes de la irrupción de la pandemia que atraviesa el mundo, los indicadores ambientales eran alarmantes, de hecho, el 2019 fue el segundo año más caliente, y la última década más caliente en la historia de la humanidad. Los indicadores afirmaban que la temperatura terrestre y oceánica global en diciembre del ese año fue la segunda más alta para ese mes en el registro de 140 años. Al final del año, la temperatura media mundial había aumentado en $1,1^{\circ} \mathrm{C}$ por encima de los niveles preindustriales (Fundación AQUAE, s.f.). Estos valores están lejos de cumplir con los objetivos de limitar el aumento de temperatura global según el Acuerdo de París.

El calentamiento global causado por las emisiones de dióxido de carbono y los gases de efecto invernadero, muestran que la humanidad no está considerando su supervivencia en el planeta y las buenas intenciones pasan a ser efímeras y los objetivos truncados en el tiempo. Nada parece detener la inminente catástrofe que experimentamos de a pocos. Como afirma Manso (2020), el cambio climático a nivel global va más allá de la temperatura y los riesgos e impactos relacionados con el clima dependen de interacciones complejas entre los peligros relacionados con el clima y la vulnerabilidad, exposición y capacidad de adaptación de los sistemas humanos y naturales.

No obstante, la realidad que vivimos hoy demostraría que en casos de urgencia, donde nos vemos amenazados, somos capaces de poner en segundo plano toda actividad para priorizar y proteger la vida humana, medidas convulsivas como esta podrían ser una luz de esperanza para pensar que frente a una catástrofe climática, estaríamos dispuestos también a tomar tales medidas, pero la historia refiere que el hombre siempre priorizó el desarrollo por sobre el cuidado del ambiente. Además, ¿estas medidas podrían devenir en una vacuna que salve al mundo?, está claro que las consecuencias que sufrimos son resultado de nuestro desarrollo y el afán desmedido de industrializar todo lo que esté a nuestro alcance y hemos acumulado gases de efecto invernadero, contaminado ríos, destruido hábitats, extinguido o desplazado especies: la cura no tiene símil con un antídoto para un virus.

A inicios de la pandemia, diversos medios de difusión mostraban reportes de cielos azules y despejados, ríos cristalinos, urbes sin ruido y hasta animales desplazados volviendo a tomar posesión de las junglas de cemento vacías a causa de la cuarentena decretada por los gobiernos. 
Este hecho muy sui generis era refrendado por el Banco Mundial (2020), aspectos nunca imaginados eran destacados como impactos positivos causados por la pandemia. En este punto, la cuestión válida es ¿fueron las medidas implementadas en la etapa crítica de la pandemia una luz de esperanza para entender que existen medidas similares para evitar una catástrofe climática? La respuesta parece obvia, no obstante, al flexibilizar las cuarentenas y reactivar los aparatos productivos volvimos a la realidad innegable. Según Zhongming et al. (2019), el secretario general de las Naciones Unidas (ONU), Antonio Guterres indicaba que; "no combatiremos el cambio climático con el virus", en la presentación de la Declaración de la Organización Meteorológica Mundial sobre el estado del clima mundial en 2019. De esta manera enfatizaba que no se debería sobrestimar el hecho de que las emisiones se redujeran durante algunos meses.

Parecía que por fin tomaría conciencia y que la nueva normalidad sería diferente; con más igualdad, justicia y por supuesto menos domino voraz contra el planeta, pero los indicadores actuales avizoran un efecto rebote y quizás más críticos porque algunos países están utilizando la crisis para revertir algunas salvaguardias ambientales (Organización de las Naciones Unidas [ONU], 2020), así los miembros del G20, en sus paquetes de rescate, están gastando un 50 \% más de lo habitual en sus sectores productivos y el consumo de combustibles fósiles, haciendo más lejana los compromisos de alcanzar la neutralidad de las emisiones de carbón para el 2050.

A manera de conclusión, la recuperación de la pandemia es importante y prioritario, pero la reparación del planeta debería ser el marco global que aspiren los gobiernos como nueva normalidad, Porque la pandemia pasará con más o menos dolor, pero el cambio climático ha venido para quedarse y cada vez será más catastrófico.

Dr. Arcadio Atencio Vargas

Director Revista Ingeniería Investiga Decano Facultad Ingeniería-UPT

\section{Referencias Bibliográficas}

Banco Mundial (2 de julio de 2020). Contaminación atmosférica: confinada pero no detenida por la COVID-19. https://www.bancomundial.org/es/news/immersivestory/2020/07/01/air-pollution-locked-down-by-covid-19-but-not-arrested

Fundación AQUAE (1 de diciembre de 2021). Evolución de la temperatura global con el paso de los años. https://www.fundacionaquae.org/calentamiento-globalprimaveras-tempranas-veranos-calidos/

Manso C., (5 de diciembre del 2021). La pandemia del COVID-19 y sus efectos en el medio ambiente. $\quad$ https://cepei.org/documents/la-pandemia-del-covid-19-y-susefectos-en-el-medio-ambiente/

Zhongming, Z., Linong, L., Wangqiang, Z. y Wei, L. (2019). Declaración de la OMM sobre el estado del clima mundial en 2019. https://cutt.ly/7U3UgrL

Organización de las Naciones Unidas (2 de octubre de 2021). No hay vacuna para el planeta, afirma el secretario general, que alerta de una actitud "suicida" de la humanidad. https://news. un.org/es/story/2020/12/1484982 